OPEN ACCESS

Edited by:

Mark Walton,

University of Oxford, UK

Reviewed by:

Giovanni Martinotti,

University G. d'Annunzio, Italy Miriam Melis,

University of Cagliari, Italy

Elyssa Margolis,

University of California San Francisco,

USA

*Correspondence:

Matthew J. Wanat

matthew.wanat@utsa.edu

Specialty section:

This article was submitted to

Addictive Disorders,

a section of the journal

Frontiers in Psychiatry

Received: 15 December 2015

Accepted: 23 February 2016

Published: 07 March 2016

Citation:

Oliva I and Wanat MJ (2016) Ventral Tegmental Area Afferents and Drug-Dependent Behaviors.

Front. Psychiatry 7:30. doi: 10.3389/fpsyt.2016.00030

\section{Ventral Tegmental Area Afferents and Drug-Dependent Behaviors}

\author{
Idaira Oliva and Matthew J. Wanat* \\ Department of Biology, Neurosciences Institute, University of Texas at San Antonio, San Antonio, TX, USA
}

Drug-related behaviors in both humans and rodents are commonly thought to arise from aberrant learning processes. Preclinical studies demonstrate that the acquisition and expression of many drug-dependent behaviors involves the ventral tegmental area (VTA), a midbrain structure comprised of dopamine, GABA, and glutamate neurons. Drug experience alters the excitatory and inhibitory synaptic input onto VTA dopamine neurons, suggesting a critical role for VTA afferents in mediating the effects of drugs. In this review, we present evidence implicating the VTA in drug-related behaviors, highlight the diversity of neuronal populations in the VTA, and discuss the behavioral effects of selectively manipulating VTA afferents. Future experiments are needed to determine which VTA afferents and what neuronal populations in the VTA mediate specific drug-dependent behaviors. Further studies are also necessary for identifying the afferent-specific synaptic alterations onto dopamine and non-dopamine neurons in the VTA following drug administration. The identification of neural circuits and adaptations involved with drug-dependent behaviors can highlight potential neural targets for pharmacological and deep brain stimulation interventions to treat substance abuse disorders.

Keywords: VTA, substance use disorders, addiction, dopamine, plasticity

\section{INTRODUCTION}

Illicit drug use is a significant global problem, with the United Nations Office on Drugs and Crime estimating that 246 million people worldwide used illicit drugs in 2013. More problematic is the high incidence of substance use disorders (SUDs), which in 2014 was estimated to afflict roughly 21.5 million people in the US, corresponding to $\sim 8 \%$ of the population (1). In addition to the personal impact of a SUD, there is a significant economic impact due to lost productivity, crime, and health care costs, which according to the US office of National Drug Policy is estimated to cost $\$ 180.8$ billion per year in the US alone.

SUDs are now recognized to exist along a continuum where the severity of the disorder is related to the number of diagnostic criteria met by an individual within the past year. According to the DSM-V, the criteria for a SUD fall into four major symptomatic clusters: impaired control (i.e., use more than intended), social impairment (i.e., substance use at the expense of personal relationships and impaired job performance), risky behavior (i.e., use despite known adverse consequences), and pharmacological effects (i.e., tolerance and withdrawal). One of the most daunting aspects in treating SUDs is the high incidence of relapse, which occurs in $\sim 40-60 \%$ of individuals (2). In drug users, exposure to drug-paired cues elicits craving that in turn can promote the possibility of a relapsing episode (3). Weakening the relationship between drugs and associated cues holds promise as a non-pharmacological method for treating SUDs (4). However, our understanding of 
the specific neural circuits and neural adaptations responsible for drug-related behaviors is incomplete.

\section{RODENT MODELS OF DRUG-DEPENDENT BEHAVIORS}

Rodent model systems are commonly employed to examine the effects of abused drugs on behavior. In this review, we will concentrate on psychostimulants and opiates, as extensive laboratory research has focused on these drug categories. The non-contingent administration of psychostimulants or opiates increases locomotor activity in rodents (5). Repeated non-contingent drug injections can lead to a progressive and long-lasting increase in this drug-induced locomotor activity, a phenomenon referred to as behavioral sensitization (5). A single injection of cocaine at high doses is also capable of eliciting sensitization $(6,7)$. Furthermore, even when no drug is administered, locomotor activity is elevated in the same context where animals received a single drug injection on the preceding day (8). These results illustrate that the association between a drug and the context where the drug is experienced is rapidly learned following a single exposure.

Drug-paired cues exert a powerful influence over behavioral actions in individuals with a SUD (3). The development of an association between drugs and cues can be examined in humans in the laboratory $(9,10)$, as well as in rodents by utilizing a conditioned place preference (CPP) behavioral paradigm (11). This rodent assay involves repeated non-contingent drug injections in one chamber and control injections in an adjacent, but contextually distinct chamber. The relative preference between the drug-paired and control contexts is subsequently assessed in a test session where the rodent can freely access both chambers in a drug-free state (11). The CPP training procedure can include an extinction phase and a reactivation test $(12,13)$, which models drug abstention and relapse observed in humans suffering from a SUD. While CPP paradigms examine contextual learning involving reinforcing outcomes, conditioned place aversion (CPA) assays examine learning involving aversive outcomes. In particular, CPA paradigms are commonly utilized to study the negative affective state following drug withdrawal $(14,15)$.

Behavioral sensitization and CPP paradigms are relatively easy to implement, but they require experimenter administered drug injections. Rodents can be readily trained to self-administer drugs via an intravenous catheter. A number of drug self-administration assays have been developed to model the behavioral symptoms observed in humans with a SUD. For example, rodents with limited access $(1 \mathrm{~h})$ to drugs in daily self-administration sessions maintain stable drug intake. However, rodents with extended access $(6 \mathrm{~h})$ to drugs increase their intake over multiple training sessions, similar to the escalated drug consumption that can be observed in individuals diagnosed with a SUD (16-18). Just as drug use does not necessarily lead to a SUD, not every rodent who self-administers drugs will develop an addiction-related phenotype. When rodents are extensively trained to self-administer drugs ( 3 months), a subset of rats exhibit characteristics found in humans with SUDs, such as persistent drug seeking in the absence of reinforcement, exerting greater effort to obtain a drug infusion, and seeking drugs despite aversive consequences (19). Rodents trained to self-administer drugs are also used to model relapse. Relapse in humans is often precipitated by three major factors: taking the drug, exposure to cues previously associated with the drug, or experiencing a stressful life-event (20-22). These same triggers (drug intake, exposure to drug-related cues, or stress) can reinstate drug-seeking behaviors in rodent drug self-administration models as well (23).

Just as with humans with a SUD, drug-dependent behaviors in rodents involve a component of learning, whether it is contextual (behavioral sensitization, CPP, CPA, and cue-induced reinstatement) or operant (drug self-administration). While numerous brain regions are involved with mediating learning and drugrelated behaviors, we will focus on the ventral tegmental area (VTA) in this review. We will also discuss the major inputs to the VTA, how these inputs influence VTA neuron activity, and present recent findings on how these VTA afferents are involved with drug-dependent behaviors.

\section{VTA INVOLVEMENT IN DRUG- DEPENDENT BEHAVIORS}

The dopamine neurons arising from the VTA that project to the nucleus accumbens (NAc) are involved with mediating the reinforcing actions of abused substances (24-26). While abused drugs increase dopamine levels in the NAc $(27,28)$, many non-habit forming drugs do not affect dopamine overflow (27). Psychostimulants affect dopamine levels primarily by altering dopamine clearance from the extracellular space $(29,30)$, whereas opiates indirectly elevate dopamine transmission by suppressing inhibitory input onto dopamine neurons (31-33).

The neural circuitry mediating any behavior is complex, though extensive research over the past few decades illustrates that the VTA is critically involved with both rewarding and aversive drug-dependent behaviors. For example, the VTA is required for behavioral sensitization induced by amphetamine or mu-opioid receptor agonists, though evidence for the involvement of the VTA in cocaine behavioral sensitization is mixed (5). The VTA is also involved with CPP for both psychostimulants and opiates (34-39), and with CPA elicited by kappa opioid receptor activation (15). The VTA is also necessary for stress-, cue-, and drug-primed reinstatement in rodents self-administering cocaine $(23,40-42)$ or heroin (43-45). While VTA-dependent behaviors are often mediated by dopamine neurons, increasing evidence illustrates the involvement of non-dopamine VTA neurons in regulating behavioral outcomes.

\section{DIVERSE NEURONAL POPULATIONS WITHIN THE VTA}

The VTA along with the neighboring substantia nigra pars compacta are the primary dopamine producing nuclei in the brain (46). Early electrophysiological recordings indicated that the VTA was comprised of two distinct neuronal populations, presumed to be dopamine neurons and local GABA interneurons $(31,47)$. However, a subset of VTA neurons exhibited a unique 
electrophysiological response to serotonin and opioid receptor agonists, providing evidence for the existence of an additional neuronal population in the VTA (48). Accumulating evidence over the past decade has highlighted the complexity of the VTA both in regards to neuronal composition and projection targets.

Dopamine neurons comprise the largest neuronal population within the VTA, as tyrosine hydroxylase $(\mathrm{TH})$, the rate-limiting enzyme for dopamine synthesis, is found in $~ 60 \%$ of VTA neurons $(46,49)$. VTA dopamine neurons typically innervate only a single target region, with different populations projecting to numerous brain nuclei, including the NAc, dorsal striatum, cortex, amygdala, globus pallidus, and lateral habenula (LHb) $(46,50,51)$. However, recent evidence indicates that dopamine neurons projecting to the medial NAc also send collaterals outside of the striatum (50). Traditionally, dopamine neurons have also been identified based upon electrophysiological properties, including the presence of a long triphasic action potential, a low baseline firing rate, burst firing, and the presence of the $I_{\mathrm{h}}$ current $(52,53)$. However, action potential duration may not be sufficient to identify the neurotransmitter content of VTA neurons $(49,54)$. Additionally, many neurons within the medial aspects of the VTA have $I_{\mathrm{h}}$ but do not contain $\mathrm{TH}$. While action potential duration and $I_{\mathrm{h}}$ are not always indicative of dopamine content, these electrophysiological properties can be related to where VTA neurons project (55-57).

The second largest neuronal population in the VTA consists of GABA neurons ( 25\%) that are commonly identified by the presence of glutamic acid decarboxylase (GAD) $(58,59)$. While initially thought to function primarily as local interneurons (31), VTA GABA neurons directly influence the activity of VTA dopamine neurons $(60,61)$ and also project to the ventral pallidum (VP), lateral hypothalamus ( $\mathrm{LH})$, and $\mathrm{LHb}$, with smaller projections to the amygdala, prefrontal cortex (PFC), and NAc (62-64). Recently, dopamine neurons were identified as an additional source of GABA in the VTA, as these neurons can synthesize GABA through an aldehyde dehydrogenase-mediated pathway (65). VTA and substantia nigra dopamine neurons package GABA into vesicles through the vesicular transporter for dopamine, indicating that GABA can be coreleased with dopamine to elicit electrophysiological effects on medium spiny neurons in both the NAc and dorsal striatum $(66,67)$.

In addition to dopamine and GABA neurons, a small percentage of VTA neurons contain vesicular glutamate transporter 2 (VGluT2), a marker for glutamate neurons. These neurons predominately reside in the medial aspects of the VTA and project to the ventral striatum, PFC, VP, amygdala, and $\mathrm{LHb}$, as well as synapse onto local dopamine neurons $(57,64,68-72)$. A subset of the VGluT2 positive neurons in the VTA also express TH and can project to the PFC and ventral striatum (70). These neurons release both dopamine and glutamate (73-77) though they are not typically released at the same site or from the same synaptic vesicles (78). While the VTA was thought to be comprised solely of dopamine and GABA neurons, recent studies illustrate that the VTA is comprised of dopamine neurons that can corelease GABA, dopamine neurons that corelease glutamate, GABA neurons, and glutamate neurons.

Optogenetic modulation of VTA neurons can elicit either appetitive or aversive behavioral outcomes depending upon the neuronal population that is targeted. Activation of dopamine neurons is acutely reinforcing and sufficient for establishing a CPP, whereas silencing dopamine neurons is aversive and elicits a CPA $(60,79,80)$. Stimulating VTA dopamine neurons also enhances reinforcing behaviors in operant tasks (81-84). In contrast, selective activation of VTA GABA neurons is aversive, elicits a CPA, and reduces reward consumption by inhibiting the activity of local VTA dopamine neurons $(60,61)$. Interestingly, activating VTA GABA neurons that synapse onto cholinergic interneurons in the NAc enhances the discrimination between neutral and aversive stimuli (63). Optogenetic activation of VGluT2-containing neurons in the VTA is also sufficient for establishing CPP, an effect that is mediated by activating local VTA dopamine neurons (72). Collectively, these studies suggest that VTA-mediated behavioral effects, including drug-dependent behaviors, likely involve a complex interplay between the distinct neuronal populations in the VTA.

\section{AFFERENT REGULATION OF THE VTA}

The VTA is innervated by a diverse array of inputs, many of which are interconnected. Large afferents to the VTA include the rostromedial tegmental nucleus (RMTg), VP, bed nucleus of the stria terminalis (BNST), LH, pedunculopontine tegmental nucleus (PPT), laterodorsal tegmental nucleus (LDT), dorsal raphe nucleus (DR), NAc, PFC, and amygdala (50, 85-87). While VTA dopamine and GABA neurons are innervated by many of the same brain regions (50), little is known about the inputs to VGluT2 positive neurons in the VTA. Below, we will discuss how notable inputs to the VTA can influence the activity of VTA neurons, how these inputs influence VTA-dependent behaviors, and recent findings on VTA afferents involved with drug-dependent behaviors.

\section{Rostromedial Tegmental Nucleus}

The RMTg (also referred to as the tail of the VTA) is a nucleus comprised of GABA neurons that function as an inhibitory relay between the LHb and the VTA $(86,88-92)$. Lesions of the RMTg demonstrate a critical role for this brain region in modulating aversive behaviors (86). Additionally, neurons in the RMTg are activated by aversive stimuli and inhibited by rewards (86). The RMTg heavily influences the firing of VTA neurons, as RMTg inactivation increases dopamine neuron firing (93), whereas stimulating the RMTg attenuates dopamine neuron firing (93-95).

The RMTg is increasingly recognized as an important nucleus in mediating the effects of abused drugs. The reinforcing effect of opiates was originally thought to arise from activation of mu-opioid receptors on VTA GABA interneurons (31), though accumulating evidence suggests the major target of opiates is instead the RMTg afferents to the VTA $(33,96,97)$. The administration of morphine decreases RMTg cell firing, which reduces the inhibition onto VTA dopamine neurons, resulting in elevated dopamine neuron firing (94-96). Indeed, selective activation of mu-opioid receptors in RMTg neurons projecting to the VTA is sufficient for eliciting a real-time place preference (98). Following opiate withdrawal, inhibiting RMTg neurons no longer elevates VTA dopamine neuron firing. This inability of the RMTg to 
disinhibit dopamine neurons is mediated in part by an alteration in VTA glutamatergic tone (93). While the RMTg projection to the VTA mediates the acute reinforcing effects of opiates (33, 96, 98), additional VTA afferent pathways are involved with dopamine neuron tolerance to opiates following withdrawal (93).

Psychostimulants also influence the activity of RMTg neurons (94). The non-contingent administration of cocaine elevates the levels of Fos, a transcription factor associated with increased neuronal activity, in RMTg neurons $(99,100)$. Interestingly, Fos levels in RMTg neurons projecting to the VTA are elevated following extinction in rats self-administering cocaine (101). The RMTg is also necessary for cocaine-related aversive behaviors that are observed once the rewarding effect of cocaine dissipates (102). Further experimentation is needed to validate whether the RMTg projection to the VTA is involved with both aversive and reinforcing behaviors elicited by cocaine.

\section{Ventral Pallidum}

The VP is involved in processing rewarding stimuli and motivated behavior (103). GABA neurons in the VP provide a large source of inhibitory input to the VTA $(87,104)$. Activating VP neuron terminals elicits inhibitory GABA currents in both dopamine and non-dopamine VTA neurons (105). The functional effect of inactivating the VP results in an increase in the population activity in putative dopamine neurons (106) though the effect on non-dopamine VTA neurons is unknown. Numerous lines of evidence implicate the VP in drug-dependent behaviors. VP neurons projecting onto dopamine and non-dopamine neurons are acutely inhibited by opiates (105). Additionally, VP lesions or pharmacological manipulations in the VP can block morphineinduced sensitization $(107,108)$, drug-induced CPP $(35,109$, $110)$, self-administration (111), and reinstatement $(40,41,112)$. VP neurons projecting to the VTA are Fos activated following cue-induced reinstatement for cocaine (101) and silencing these neurons is sufficient for blocking cue-induced reinstatement (113). While VP neurons project to both dopamine and nondopamine neurons in the VTA (105), it is unclear what neuronal population(s) in the VTA are influenced by the VP inputs during drug-dependent behaviors.

\section{Bed Nucleus of the Stria Terminalis}

The BNST is involved in mediating fear and anxiety (114-120) and is considered to be a relay nucleus between stress and reward pathways $(121,122)$. The neuronal composition of the BNST is diverse, with efferent populations of GABA and glutamate neurons along with local GABA and cholinergic interneurons (122, 123). BNST neurons also express an assortment of neuropeptides including neuropeptide $Y$, corticotropin-releasing factor, enkephalin, dynorphin, and substance P (124). Electrical stimulation of the BNST exerts an excitatory influence on midbrain dopamine neurons $(122,125,126)$ and elevates dopamine release in the NAc (127). Recent studies suggest that this excitatory effect on dopamine neurons is predominately mediated through GABA BNST neurons disinhibiting VTA GABA neurons, resulting in anxiolytic and rewarding behavioral outcomes (128-130). Interesting, glutamate neurons in the BNST also innervate VTA GABA neurons, and activation of these neurons elicits aversive and anxiogenic behaviors (129). Within the context of drug-dependent behaviors, local pharmacological manipulations illustrate a critical role of the BNST in the stress-induced reinstatement of drug seeking (41, 131, 132). Furthermore, recent studies implicate the BNST-VTA pathway in the locomotor-activating effects of cocaine (133) and in the expression of cocaine CPP (134), though the involvement of this pathway in other drug-dependent behaviors has not yet been explored.

\section{Lateral Hypothalamus}

The LH is critical for the expression of motivated behaviors including feeding and drug seeking (135). The LH provides both glutamate and GABA inputs to the VTA $(85,136)$. In addition, LH neurons projecting to the VTA also contain neuropeptides such as neurotensin and orexin/hypocretin $(137,138)$. Electrical stimulation of the LH increases the activity of putative dopamine neurons and inhibits the activity of putative GABA neurons in the VTA (139). Many lines of evidence demonstrate that activation of this LH-VTA pathway is reinforcing. Rodents will readily self-stimulate for electrical activation of the $\mathrm{LH}$, but this behavioral effect is inhibited by dopamine receptor antagonism (140) or inactivation of the VTA (141). Furthermore, optogenetic activation of LH inputs to the VTA also supports self-stimulation through a neurotensin-dependent mechanism (142).

Accumulating evidence over the past decade highlights the importance of orexin-containing neurons in feeding, the sleep/wake cycle, and drug-dependent behaviors (143). Orexin-producing neurons are exclusively localized within the hypothalamus and project widely throughout the brain (144), though it is the projection to the VTA that is heavily involved with drug-dependent behaviors. Intra-VTA injections of orexin receptor antagonists attenuate morphine CPP $(145,146)$, which is consistent with the reduced morphine dependence observed in orexin-deficient mice (147). Conversely, intra-VTA administration of orexin reinstates morphine CPP (12). Orexin antagonists targeting the VTA also diminish behavioral sensitization to cocaine (148), cocaine self-administration (149), and cue-induced reinstatement (150). Interestingly, orexin neurons in the LH also contain dynorphin, which inhibits the activity of VTA dopamine neurons. A recent study suggests that orexin in the VTA facilitates drug-related behaviors in part through attenuating the effects of dynorphin (149). Although the orexin-containing neurons in the $\mathrm{LH}$ have received considerable attention in the context of addiction, additional neuronal populations in the LH-VTA pathway are also likely involved in drug-dependent behaviors, as the nonorexin-producing neurons in the LH are Fos activated following cue-induced reinstatement (101).

\section{Laterodorsal Tegmental Nucleus and Pedunculopontine Tegmental Nucleus}

The LDT and PPT are involved in modulating arousal and rewarddriven behaviors $(92,151-154)$. These nuclei are comprised of distinct populations of acetylcholine, GABA, and glutamate neurons that project to the midbrain dopamine system (155, 156). Anatomical studies indicate that the VTA primarily receives input from the $\operatorname{LDT}(87,155,157)$. In vivo electrophysiological 
experiments illustrate that electrical stimulation of the LDT elicits burst firing in putative VTA dopamine neurons (158). Selective activation of LDT inputs to the VTA evokes excitatory currents in VTA dopamine neurons projecting to the lateral NAc (92). Stimulating this LDT-VTA pathway in vivo elicits CPP and reinforces operant responding $(92,154)$. Increasing evidence indicates that the LDT is also involved in drug-dependent behaviors. Specifically, local pharmacological manipulations demonstrate the LDT is critical for the acquisition and expression of cocaine CPP (159), as well as with cocaine-primed reinstatement of drug seeking (160). Interestingly, the cholinergic neurons of the LDT are involved with the behavioral responsiveness to cocaine-paired cues (161). Further studies are needed to ascertain whether drug-dependent behaviors also involve the GABA and glutamate projections from the LDT to the VTA.

Whereas the VTA is preferentially innervated by the LDT, the PPT primarily targets the substantia nigra $(87,155)$. Although the anatomical evidence indicates there is a small PPT projection to the VTA $(87,155)$, electrophysiological studies in vivo and in vitro suggest a functional relationship exists between the PPT and VTA $(106,162,163)$. The discrepancy between the anatomical and electrophysiological studies is unclear, though proposed explanations include the possibility that a single PPT neuron innervates numerous VTA neurons or that electrical stimulation excites fibers of passage or nearby regions, such as the LDT (87). Regardless, electrical stimulations targeting the PPT increases burst firing of putative VTA dopamine neurons (106), while PPT inactivation reduces dopamine neuron firing to salient stimuli (162). The PPT is also implicated in drugdependent behaviors, as lesions attenuate amphetamine- and morphine-induced locomotor activity (164), and PPT inactivation reduces cocaine-primed reinstatement of drug seeking (160). PPT lesions reduce both heroin self-administration and morphine CPP $(165,166)$. However, PPT cholinergic neurons are not involved with cocaine self-administration, heroin selfadministration, cocaine CPP, and heroin CPP (167), suggesting the involvement of PPT glutamate and/or GABA neurons in these drug-related behaviors.

\section{Dorsal Raphe}

The DR is the primary source of serotonin in the brain, but also contains glutamate (85), GABA (168), and dopamine neurons (169). While the DR is often studied within the context of controlling affective state (170), it is also involved in reinforcing instrumental behavior (171). Serotonin exerts a variety of electrophysiological responses in VTA neurons. The predominant in vitro response in putative dopamine neurons is excitatory, though a small proportion of dopamine neurons are inhibited by serotonin (172). In contrast, equal numbers of putative GABA neurons are excited and inhibited by serotonin (172). The net effect of these electrophysiological responses appears to be excitatory, as in vivo intra-VTA administration of serotonin elevates dopamine levels in the NAc (173).

Serotonin influences drug-related behaviors (174), which could involve the DR serotonin neurons projecting to the VTA. However, the DR projection to the VTA is primarily comprised of glutamate neurons that predominantly innervate dopamine neurons $(85,87,175)$. Activation of DR glutamate neurons evokes excitatory currents in VTA dopamine neurons and elicits dopamine release in the NAc (175). Selective activation of the non-serotonergic DR-VTA pathway reinforces instrumental behavior and is sufficient for eliciting CPP $(175,176)$. In contrast, activation of serotonergic DR neurons projecting to the VTA is only weakly reinforcing (176). These anatomical and behavioral findings suggest that the VTA is likely not a primary locus where serotonin acts to influence drug-related behaviors. Instead, the non-serotonergic DR neurons projecting to the VTA are well positioned to mediate drug-dependent behaviors, though this has not yet been experimentally examined.

\section{Nucleus Accumbens}

GABA neurons in the NAc project to the VTA and are thought to mediate a "long-loop" inhibitory feedback to regulate dopamine neuron activity (177). Mu-opioid receptor agonists acutely inhibit the GABA afferents from the NAc to the VTA $(33,178)$. The inhibitory transmission from the NAc inputs onto VTA GABA neurons is enhanced following repeated injections of cocaine, which in turn disinhibits VTA dopamine neurons (179). In addition to being influenced by opiates and psychostimulants, the NAc afferents to the VTA are Fos activated during cocaine cue-induced reinstatement (101). While these results suggest the NAc-VTA pathway is involved in drug-related behaviors, no experiments to date have examined the behavioral effect of selectively perturbing this pathway.

\section{Prefrontal Cortex}

The medial PFC mediates a variety of cognitive functions (180), is involved in the reinstatement of drug-seeking behavior (23), and exhibits Fos activation following an acute administration of amphetamine (181). The VTA receives a dense glutamate projection from the medial PFC (85), with pyramidal neurons synapsing onto both dopamine and non-dopamine VTA neurons $(62,182)$. Electrically stimulating the PFC can either inhibit or excite putative dopamine neurons within the VTA $(183,184)$. Whereas single pulse or low frequency PFC stimulation inhibits a majority of VTA dopamine neurons (183-185), burst stimulation of the PFC excites $>90 \%$ of VTA dopamine neurons (184). The mechanism behind the dopamine neuron excitation is unclear, as VTA dopamine neurons receive sparse input from the PFC $(87,186)$, with $<15 \%$ of VTA dopamine neurons being excited by selective activation of medial PFC inputs (50). These findings collectively suggest the medial PFC preferentially targets VTA GABA neurons, though the relevance of this PFC-VTA pathway in drug-dependent behaviors has not been examined.

\section{Amygdala}

The amygdala is an interconnected group of nuclei involved with attributing emotional value to cues $(187,188)$. The VTA receives amygdala input arising from the central nucleus of the amygdala (CeA) subdivision $(87,189)$. The CeA contains predominantly GABA neurons and is involved with fear conditioning $(187,188$, $190)$, as well as with mediating the general motivational influence 
of rewarding cues $(191,192)$. In the context of drug-dependent behaviors, the CeA facilitates the expression of conditioned responding (193) and is also involved with mediating stressinduced reinstatement of drug-seeking behavior (194, 195). While the CeA projects to the VTA, it is currently unknown how this pathway influences VTA neuron activity and whether it is crucial for drug-dependent behaviors.

\section{DRUG-INDUCED SYNAPTIC PLASTICITY ON VTA NEURONS}

The transition of an individual from drug naive or casual drug user to SUDs involves changes in the function of specific neural circuits (196). Given the importance of the VTA in drug-related behaviors, the synaptic adaptations in VTA dopamine neurons have been extensively studied and reviewed elsewhere (197-201). Numerous studies from a variety of laboratories have consistently demonstrated an increase in excitatory synaptic strength onto VTA dopamine neurons after in vivo exposure to abused drugs (202-208). Many of these studies examined the effect of drugs on the ratio of the AMPA receptor current to the NMDA receptor current (AMPA/NMDA) in VTA neurons, which allows for comparing the excitatory synaptic strength between different groups of animals (i.e., drug treated vs. control). In vivo exposure to drugs of abuse increases the AMPA/NMDA (202-204, 206, 207), which is mediated by insertion of calcium-permeable AMPA receptors and removal of NMDA receptors in VTA dopamine neurons $(205,208)$.

In addition to the excitatory synaptic alterations in VTA dopamine neurons, in vivo exposure to drugs also modulates inhibitory synaptic inputs to the VTA. For example, repeated injections of cocaine potentiate the NAc inhibitory input to VTA GABA neurons, which results in a disinhibition of dopamine neurons (179). This disinhibition also facilitates the ability to elicit excitatory long-term potentiation (LTP) in VTA dopamine neurons (209). VTA dopamine neurons are also capable of undergoing inhibitory LTP. Furthermore, this inhibitory LTP is blocked following an in vivo exposure to opiates $(210,211)$. A myriad of drug-induced synaptic alterations have been reported, though it is important to note that the full complement of electrophysiological changes and the duration of these alterations in VTA neurons depends upon the drug, the drug dose, and the manner the drug is administered $(202-204,206,207,212)$. Few studies to date have examined whether these drug-induced synaptic changes occur in an afferent-specific manner $(179,212)$. Indeed, in vivo exposure to different classes of abused drugs results in alterations in distinct excitatory inputs to VTA dopamine neurons (212). Although much has been learned regarding synaptic alterations in the VTA following non-contingent injections of abused drugs, additional studies are needed to ascertain the similarities and differences in the synaptic changes evoked by different classes of abused drugs (psychostimulants, opiates, alcohol, nicotine, etc.). Furthermore, electrophysiological studies are also needed to identify which VTA afferents and what VTA neuronal populations undergo synaptic alterations following contingent drug self-administration.

\section{CONCLUSION}

The high incidence of relapse illustrates the need for identifying new therapeutic approaches for the treatment of SUDs. The treatment of opioid dependence is complicated by the severe withdrawal symptoms experienced by individuals when ceasing drug intake. The current treatment options for opioid SUDs typically focus on opioid maintenance with methadone or buprenorphine and detoxification with alpha-2 receptor agonists. However, these current treatment options often result in relapse (213). Currently there is no FDA-approved pharmacotherapy for the treatment of cocaine SUDs, though $\mathrm{N}$-acetylcysteine is a promising and well-tolerated drug that reduces cocaine-seeking in rodents and craving in cocainedependent humans (214-217). Over the past decade, research on effective pharmacological treatments for alcohol SUDs has identified many potential targets, including opioid receptors (218), dopamine receptors (219), glutamate receptors (220), GABA receptors (221), and adrenergic receptors (222). Preclinical research highlighted the cannabinoid system as a promising target for multiple SUDs $(223,224)$. However, a cardiovascular clinical study examining the efficacy of rimanobant, a cannabinoid receptor antagonist, elicited severed negative neuropsychiatric effects (225) and has dampened enthusiasm for targeting the endocannabinoid system for treating SUDs. Unfortunately, no single pharmacotherapy currently exists for treating a broad spectrum of SUDs.

An alternative therapeutic direction for the treatment of SUDs involves the use of deep brain stimulation (DBS), which commonly has been utilized for the treatment of movement disorders. In preclinical studies, DBS targeting the NAc reduced cocaine behavioral sensitization (226), morphine CPP (227), reinstatement of heroin-seeking (228), and reinstatement of cocaine-seeking (229-231). Additionally, DBS targeting the LHb reduces cocaine self-administration and the reinstatement of cocaine-seeking (232). Consistent with the rodent DBS experiments, clinical studies indicate a complete remission or prolonged cessation of heroin use after DBS in the NAc in humans (233, 234). A considerable drawback of implementing DBS in humans is the invasive nature of implanting the probe. However, a couple of recent reports illustrate that non-invasive transcranial magnetic stimulation of the PFC is effective at reducing drug use and craving $(235,236)$. While there are promising new therapeutic approaches for treating SUDs, the ultimate goal for any intervention is to be effective and as specific as possible to limit side effects. Thus, additional basic science research is needed for identifying the specific neural circuits and adaptations responsible for the development of drug-dependent behaviors.

The implementation of optogenetic and chemogenetic approaches in behavioral experiments has validated and identified specific neural circuits that mediate a range of appetitive and aversive behaviors. Many of these studies manipulated brain regions implicated in SUDs (237), though relatively few have modulated neural circuits within the context of drug-dependent behaviors $(98,113,133)$. While activity within the VTA is central to numerous drug-dependent behaviors, many questions remain. Future experiments are needed to (i) determine which 
VTA afferents and what neuronal populations in the VTA mediate a particular drug-dependent behavior and (ii) elucidate the associated afferent-specific synaptic changes on both dopamine and non-dopamine neurons within the VTA. Identifying the neural circuits and adaptations responsible for drug-dependent behaviors in rodents can highlight specific neural circuits for targeted pharmacological and DBS therapeutic interventions to treat humans suffering from a SUD.

\section{REFERENCES}

1. Center for Behavioral Health Statistics and Quality. Behavioral Health Trends in the United States: Results from the 2014 National Survey on Drug Use and Health. (HHS Publication No. SMA 15-4927, NSDUH Series H-50) (2015).

2. McLellan AT, Lewis DC, O'Brien CP, Kleber HD. Drug dependence, a chronic medical illness: implications for treatment, insurance, and outcomes evaluation. JAMA (2000) 284:1689-95. doi:10.1001/jama.284.13.1689

3. O'Brien CP, Childress AR, Ehrman R, Robbins SJ. Conditioning factors in drug abuse: can they explain compulsion? J Psychopharmacol (1998) 12:15-22. doi:10.1177/026988119801200103

4. Xue YX, Luo YX, Wu P, Shi HS, Xue LF, Chen C, et al. A memory retrieval-extinction procedure to prevent drug craving and relapse. Science (2012) 336:241-5. doi:10.1126/science. 1215070

5. Vanderschuren LJ, Kalivas PW. Alterations in dopaminergic and glutamatergic transmission in the induction and expression of behavioral sensitization: a critical review of preclinical studies. Psychopharmacology (Berl) (2000) 151:99-120. doi:10.1007/s002130000493

6. Jackson HC, Nutt DJ. A single preexposure produces sensitization to the locomotor effects of cocaine in mice. Pharmacol Biochem Behav (1993) 45:733-5. doi:10.1016/0091-3057(93)90533-Y

7. Wanat MJ, Sparta DR, Hopf FW, Bowers MS, Melis M, Bonci A. Strain specific synaptic modifications on ventral tegmental area dopamine neurons after ethanol exposure. Biol Psychiatry (2009) 65:646-53. doi:10.1016/j. biopsych.2008.10.042

8. Dong Y, Saal D, Thomas M, Faust R, Bonci A, Robinson T, et al. Cocaineinduced potentiation of synaptic strength in dopamine neurons: behavioral correlates in GluRA(-/-) mice. Proc Natl Acad Sci U S A (2004) 101:14282-7. doi:10.1073/pnas.0401553101

9. Mayo LM, Fraser D, Childs E, Momenan R, Hommer DW, de Wit H, et al. Conditioned preference to a methamphetamine-associated contextual cue in humans. Neuropsychopharmacology (2013) 38:921-9. doi:10.1038/ npp. 2013.3

10. Mayo LM, de Wit H. Acquisition of responses to a methamphetamine-associated cue in healthy humans: self-report, behavioral, and psychophysiological measures. Neuropsychopharmacology (2015) 40:1734-41. doi:10.1038/ npp.2015.21

11. Tzschentke TM. Measuring reward with the conditioned place preference paradigm: a comprehensive review of drug effects, recent progress and new issues. Prog Neurobiol(1998) 56:613-72. doi:10.1016/S0301-0082(98)00060-4

12. Harris GC, Wimmer M, Aston-Jones G. A role for lateral hypothalamic orexin neurons in reward seeking. Nature (2005) 437:556-9. doi:10.1038/ nature 04071

13. Bruchas MR, Schindler AG, Shankar H, Messinger DI, Miyatake M, Land BB, et al. Selective p38alpha MAPK deletion in serotonergic neurons produces stress resilience in models of depression and addiction. Neuron (2011) 71:498-511. doi:10.1016/j.neuron.2011.06.011

14. Bals-Kubik R, Ableitner A, Herz A, Shippenberg TS. Neuroanatomical sites mediating the motivational effects of opioids as mapped by the conditioned place preference paradigm in rats. J Pharmacol Exp Ther (1993) 264:489-95.

15. Chefer VI, Backman CM, Gigante ED, Shippenberg TS. Kappa opioid receptors on dopaminergic neurons are necessary for kappa-mediated place aversion. Neuropsychopharmacology (2013) 38:2623-31. doi:10.1038/npp.2013.171

16. Ahmed SH, Koob GF. Transition from moderate to excessive drug intake: change in hedonic set point. Science (1998) 282:298-300. doi:10.1126/ science.282.5387.298

\section{AUTHOR CONTRIBUTIONS}

MW and IO contributed to the writing of this review article.

\section{FUNDING}

This work was supported by National Institutes of Health Grant DA033386 (MW).

17. Ahmed SH, Koob GF. Long-lasting increase in the set point for cocaine self-administration after escalation in rats. Psychopharmacology (Berl) (1999) 146:303-12. doi:10.1007/s002130051121

18. Ahmed SH, Walker JR, Koob GF. Persistent increase in the motivation to take heroin in rats with a history of drug escalation. Neuropsychopharmacology (2000) 22:413-21. doi:10.1016/S0893-133X(99)00133-5

19. Deroche-Gamonet V, Belin D, Piazza PV. Evidence for addiction-like behavior in the rat. Science (2004) 305:1014-7. doi:10.1126/science.1099020

20. Jaffe JH, Cascella NG, Kumor KM, Sherer MA. Cocaine-induced cocaine craving. Psychopharmacology (Berl) (1989) 97:59-64. doi:10.1007/BF00443414

21. Carter BL, Tiffany ST. Meta-analysis of cue-reactivity in addiction research. Addiction (1999) 94:327-40. doi:10.1046/j.1360-0443.1999.9433273.x

22. Sinha R. How does stress increase risk of drug abuse and relapse? Psychopharmacology (Berl) (2001) 158:343-59. doi:10.1007/s002130100917

23. Kalivas PW, McFarland K. Brain circuitry and the reinstatement of cocaine-seeking behavior. Psychopharmacology (Berl) (2003) 168:44-56. doi:10.1007/s00213-003-1393-2

24. Nestler EJ. Is there a common molecular pathway for addiction? Nat Neurosci (2005) 8:1445-9. doi:10.1038/nn1578

25. Wise RA. Dopamine and reward: the anhedonia hypothesis 30 years on. Neurotox Res (2008) 14:169-83. doi:10.1007/BF03033808

26. Wanat MJ, Willuhn I, Clark JJ, Phillips PE. Phasic dopamine release in appetitive behaviors and drug addiction. Curr Drug Abuse Rev (2009) 2:195-213. doi:10.2174/1874473710902020195

27. Di Chiara G, Imperato A. Drugs abused by humans preferentially increase synaptic dopamine concentrations in the mesolimbic system of freely moving rats. Proc Natl Acad Sci U S A (1988) 85:5274-8. doi:10.1073/pnas.85.14.5274

28. Tanda G, Pontieri FE, Di Chiara G. Cannabinoid and heroin activation of mesolimbic dopamine transmission by a common mul opioid receptor mechanism. Science (1997) 276:2048-50. doi:10.1126/science.276.5321.2048

29. Kuhr WG, Ewing AG, Near JA, Wightman RM. Amphetamine attenuates the stimulated release of dopamine in vivo. J Pharmacol Exp Ther (1985) 232:388-94.

30. Ritz MC, Lamb RJ, Goldberg SR, Kuhar MJ. Cocaine receptors on dopamine transporters are related to self-administration of cocaine. Science (1987) 237:1219-23. doi:10.1126/science.2820058

31. Johnson SW, North RA. Opioids excite dopamine neurons by hyperpolarization of local interneurons. J Neurosci (1992) 12:483-8.

32. Melis M, Gessa GL, Diana M. Different mechanisms for dopaminergic excitation induced by opiates and cannabinoids in the rat midbrain. Prog Neuropsychopharmacol Biol Psychiatry (2000) 24:993-1006. doi:10.1016/ S0278-5846(00)00119-6

33. Matsui A, Jarvie BC, Robinson BG, Hentges ST, Williams JT. Separate GABA afferents to dopamine neurons mediate acute action of opioids, development of tolerance, and expression of withdrawal. Neuron (2014) 82:1346-56. doi:10.1016/j.neuron.2014.04.030

34. Bozarth MA. Neuroanatomical boundaries of the reward-relevant opiate-receptor field in the ventral tegmental area as mapped by the conditioned place preference method in rats. Brain Res (1987) 414:77-84. doi:10.1016/0006-8993(87)91327-8

35. Gong W, Neill D, Justice JB Jr. 6-Hydroxydopamine lesion of ventral pallidum blocks acquisition of place preference conditioning to cocaine. Brain Res (1997) 754:103-12. doi:10.1016/S0006-8993(97)00059-0

36. McBride WJ, Murphy JM, Ikemoto S. Localization of brain reinforcement mechanisms: intracranial self-administration and intracranial place-conditioning studies. Behav Brain Res (1999) 101:129-52. doi:10.1016/ S0166-4328(99)00022-4 
37. Wang B, Luo F, Ge XC, Fu AH, Han JS. Effects of lesions of various brain areas on drug priming or footshock-induced reactivation of extinguished conditioned place preference. Brain Res (2002) 950:1-9. doi:10.1016/ S0006-8993(02)02980-3

38. Harris GC, Aston-Jones G. Critical role for ventral tegmental glutamate in preference for a cocaine-conditioned environment. Neuropsychopharmacology (2003) 28:73-6. doi:10.1038/sj.npp.1300011

39. Sticht M, Mitsubata J, Tucci M, Leri F. Reacquisition of heroin and cocaine place preference involves a memory consolidation process sensitive to systemic and intra-ventral tegmental area naloxone. Neurobiol Learn Mem (2010) 93:248-60. doi:10.1016/j.nlm.2009.10.005

40. McFarland K, Kalivas PW. The circuitry mediating cocaine-induced reinstatement of drug-seeking behavior. J Neurosci (2001) 21:8655-63.

41. McFarland K, Davidge SB, Lapish CC, Kalivas PW. Limbic and motor circuitry underlying footshock-induced reinstatement of cocaine-seeking behavior. J Neurosci (2004) 24:1551-60. doi:10.1523/JNEUROSCI.4177-03.2004

42. Mahler SV, Smith RJ, Aston-Jones G. Interactions between VTA orexin and glutamate in cue-induced reinstatement of cocaine seeking in rats. Psychopharmacology (Berl) (2013) 226:687-98. doi:10.1007/ s00213-012-2681-5

43. Stewart J. Reinstatement of heroin and cocaine self-administration behavior in the rat by intracerebral application of morphine in the ventral tegmental area. PharmacolBiochemBehav(1984)20:917-23.doi:10.1016/0091-3057(84)90017-0

44. Bossert JM, Liu SY, Lu L, Shaham Y. A role of ventral tegmental area glutamate in contextual cue-induced relapse to heroin seeking. J Neurosci (2004) 24:10726-30. doi:10.1523/JNEUROSCI.3207-04.2004

45. Wang B, You ZB, Wise RA. Heroin self-administration experience establishes control of ventral tegmental glutamate release by stress and environmental stimuli. Neuropsychopharmacology (2012) 37:2863-9. doi:10.1038/npp.2012.167

46. Swanson LW.The projections of theventral tegmental area and adjacentregions: a combined fluorescent retrograde tracer and immunofluorescence study in the rat. Brain Res Bull (1982) 9:321-53. doi:10.1016/0361-9230(82)90145-9

47. Johnson SW, North RA. Two types of neurone in the rat ventral tegmental area and their synaptic inputs. J Physiol (1992) 450:455-68. doi:10.1113/ jphysiol.1992.sp019136

48. Cameron DL, Wessendorf MW, Williams JT. A subset of ventral tegmental area neurons is inhibited by dopamine, 5-hydroxytryptamine and opioids. Neuroscience (1997) 77:155-66. doi:10.1016/S0306-4522(96)00444-7

49. Margolis EB, Lock H, Hjelmstad GO, Fields HL. The ventral tegmental area revisited: is there an electrophysiological marker for dopaminergic neurons? J Physiol (2006) 577:907-24. doi:10.1113/jphysiol.2006.117069

50. Beier KT, Steinberg EE, DeLoach KE, Xie S, Miyamichi K, Schwarz L, et al. Circuit architecture of VTA dopamine neurons revealed by systematic input-output mapping. Cell (2015) 162:622-34. doi:10.1016/j. cell.2015.07.015

51. Menegas W, Bergan JF, Ogawa SK, Isogai Y, Umadevi Venkataraju K, Osten $\mathrm{P}$, et al. Dopamine neurons projecting to the posterior striatum form an anatomically distinct subclass. Elife (2015) 4:e10032. doi:10.7554/ eLife. 10032

52. Grace AA, Bunney BS. Nigral dopamine neurons: intracellular recording and identification with L-dopa injection and histofluorescence. Science (1980) 210:654-6. doi:10.1126/science.7433992

53. Grace AA, Onn SP. Morphology and electrophysiological properties of immunocytochemically identified rat dopamine neurons recorded in vitro. J Neurosci (1989) 9:3463-81.

54. Ungless MA. Dopamine: the salient issue. Trends Neurosci (2004) 27:702-6. doi:10.1016/j.tins.2004.10.001

55. Lammel S, Hetzel A, Hackel O, Jones I, Liss B, Roeper J. Unique properties of mesoprefrontal neurons within a dual mesocorticolimbic dopamine system. Neuron (2008) 57:760-73. doi:10.1016/j.neuron.2008.01.022

56. Margolis EB, Mitchell JM, Ishikawa J, Hjelmstad GO, Fields HL. Midbrain dopamine neurons: projection target determines action potential duration and dopamine D(2) receptor inhibition. JNeurosci (2008) 28:8908-13. doi:10.1523/JNEUROSCI.1526-08.2008

57. Hnasko TS, Hjelmstad GO, Fields HL, Edwards RH. Ventral tegmental area glutamate neurons: electrophysiological properties and projections. J Neurosci (2012) 32:15076-85. doi:10.1523/JNEUROSCI.3128-12.2012

58. Nair-Roberts RG, Chatelain-Badie SD, Benson E, White-Cooper H, Bolam JP, Ungless MA. Stereological estimates of dopaminergic, GABAergic and glutamatergic neurons in the ventral tegmental area, substantia nigra and retrorubral field in the rat. Neuroscience (2008) 152:1024-31. doi:10.1016/j. neuroscience.2008.01.046

59. Margolis EB, Toy B, Himmels P, Morales M, Fields HL. Identification of rat ventral tegmental area GABAergic neurons. PLoS One (2012) 7:e42365. doi:10.1371/journal.pone.0042365

60. Tan KR, Yvon C, Turiault M, Mirzabekov JJ, Doehner J, Labouebe G, et al. GABA neurons of the VTA drive conditioned place aversion. Neuron (2012) 73:1173-83. doi:10.1016/j.neuron.2012.02.015

61. van Zessen R, Phillips JL, Budygin EA, Stuber GD. Activation of VTA GABA neurons disrupts reward consumption. Neuron (2012) 73:1184-94. doi:10.1016/j.neuron.2012.02.016

62. Carr DB, Sesack SR. GABA-containing neurons in the rat ventral tegmental area project to the prefrontal cortex. Synapse (2000) 38:114-23. doi:10.1002/1098-2396(200011)38:2<114:AID-SYN2>3.0.CO;2-R

63. Brown MT, Tan KR, O’Connor EC, Nikonenko I, Muller D, Luscher C. Ventral tegmental area GABA projections pause accumbal cholinergic interneurons to enhance associative learning. Nature (2012) 492:452-6. doi:10.1038/nature11657

64. Taylor SR, Badurek S, Dileone RJ, Nashmi R, Minichiello L, Picciotto MR. GABAergic and glutamatergic efferents of the mouse ventral tegmental area. J Comp Neurol (2014) 522:3308-34. doi:10.1002/cne.23603

65. Kim JI, Ganesan S, Luo SX, Wu YW, Park E, Huang EJ, et al. Aldehyde dehydrogenase lal mediates a GABA synthesis pathway in midbrain dopaminergic neurons. Science (2015) 350:102-6. doi:10.1126/science.aac4690

66. Tritsch NX, Ding JB, Sabatini BL. Dopaminergic neurons inhibit striatal output through non-canonical release of GABA. Nature (2012) 490:262-6. doi:10.1038/nature11466

67. Tritsch NX, Oh WJ, Gu C, Sabatini BL. Midbrain dopamine neurons sustain inhibitory transmission using plasma membrane uptake of GABA, not synthesis. Elife (2014) 3:e01936. doi:10.7554/eLife.01936

68. Kawano M, Kawasaki A, Sakata-Haga H, Fukui Y, Kawano H, Nogami H, et al. Particular subpopulations of midbrain and hypothalamic dopamine neurons express vesicular glutamate transporter 2 in the rat brain. J Comp Neurol (2006) 498:581-92. doi:10.1002/cne.21054

69. Yamaguchi T, Sheen W, Morales M. Glutamatergic neurons are present in the rat ventral tegmental area. Eur JNeurosci (2007) 25:106-18. doi:10.1111/j.1460-9568.2006.05263.x

70. Yamaguchi T, Wang HL, Li X, Ng TH, Morales M. Mesocorticolimbic glutamatergic pathway. JNeurosci (2011) 31:8476-90. doi:10.1523/ JNEUROSCI.1598-11.2011

71. Gorelova N, Mulholland PJ, Chandler LJ, Seamans JK. The glutamatergic component of the mesocortical pathway emanating from different subregions of the ventral midbrain. Cereb Cortex (2012) 22:327-36. doi:10.1093/cercor/bhr107

72. Wang HL, Qi J, Zhang S, Wang H, Morales M. Rewarding effects of optical stimulation of ventral tegmental area glutamatergic neurons. JNeurosci (2015) 35:15948-54. doi:10.1523/JNEUROSCI.3428-15.2015

73. Chuhma N, Zhang H, Masson J, Zhuang X, Sulzer D, Hen R, et al. Dopamine neurons mediate a fast excitatory signal via their glutamatergic synapses. J Neurosci (2004) 24:972-81. doi:10.1523/JNEUROSCI.4317-03.2004

74. Chuhma N, Choi WY, Mingote S, Rayport S. Dopamine neuron glutamate cotransmission: frequency-dependent modulation in the mesoventromedial projection. Neuroscience (2009) 164:1068-83. doi:10.1016/j. neuroscience.2009.08.057

75. Stuber GD, Hnasko TS, Britt JP, Edwards RH, Bonci A. Dopaminergic terminals in the nucleus accumbens but not the dorsal striatum corelease glutamate. J Neurosci (2010) 30:8229-33. doi:10.1523/JNEUROSCI.1754-10.2010

76. Tecuapetla F, Patel JC, Xenias H, English D, Tadros I, Shah F, etal. Glutamatergic signaling by mesolimbic dopamine neurons in the nucleus accumbens. J Neurosci (2010) 30:7105-10. doi:10.1523/JNEUROSCI.0265-10.2010

77. Chuhma N, Mingote S, Moore H, Rayport S. Dopamine neurons control striatal cholinergic neurons via regionally heterogeneous dopamine and glutamate signaling. Neuron (2014) 81:901-12. doi:10.1016/j.neuron.2013.12.027

78. Zhang S, Qi J, Li X, Wang HL, Britt JP, Hoffman AF, et al. Dopaminergic and glutamatergic microdomains in a subset of rodent mesoaccumbens axons. Nat Neurosci (2015) 18:386-92. doi:10.1038/nn.3945

79. Tsai HC, Zhang F, Adamantidis A, Stuber GD, Bonci A, de Lecea L, et al. Phasic firing in dopaminergic neurons is sufficient for behavioral conditioning. Science (2009) 324:1080-4. doi:10.1126/science.1168878 
80. Ilango A, Kesner AJ, Keller KL, Stuber GD, Bonci A, Ikemoto S. Similar roles of substantia nigra and ventral tegmental dopamine neurons in reward and aversion. J Neurosci (2014) 34:817-22. doi:10.1523/JNEUROSCI.1703-13.2014

81. Adamantidis AR, Tsai HC, Boutrel B, Zhang F, Stuber GD, Budygin EA, et al. Optogenetic interrogation of dopaminergic modulation of the multiple phases of reward-seeking behavior. J Neurosci (2011) 31:10829-35. doi:10.1523/JNEUROSCI.2246-11.2011

82. Steinberg EE, Keiflin R, Boivin JR, Witten IB, Deisseroth K, Janak PH. A causal link between prediction errors, dopamine neurons and learning. Nat Neurosci (2013) 16:966-73. doi:10.1038/nn.3413

83. Ilango A, Kesner AJ, Broker CJ, Wang DV, Ikemoto S. Phasic excitation of ventral tegmental dopamine neurons potentiates the initiation of conditioned approach behavior: parametric and reinforcement-schedule analyses. Front Behav Neurosci (2014) 8:155. doi:10.3389/fnbeh.2014.00155

84. Pascoli V, Terrier J, Hiver A, Luscher C. Sufficiency of mesolimbic dopamine neuron stimulation for the progression to addiction. Neuron (2015) 88:1054-66. doi:10.1016/j.neuron.2015.10.017

85. Geisler S, Derst C, Veh RW, Zahm DS. Glutamatergic afferents of the ventral tegmental area in the rat. J Neurosci (2007) 27:5730-43. doi:10.1523/ JNEUROSCI.0012-07.2007

86. Jhou TC, Fields HL, Baxter MG, Saper CB, Holland PC. The rostromedial tegmental nucleus (RMTg), a GABAergic afferent to midbrain dopamine neurons, encodes aversive stimuli and inhibits motor responses. Neuron (2009) 61:786-800. doi:10.1016/j.neuron.2009.02.001

87. Watabe-Uchida M, Zhu L, Ogawa SK, Vamanrao A, Uchida N. Whole-brain mapping of direct inputs to midbrain dopamine neurons. Neuron (2012) 74:858-73. doi:10.1016/j.neuron.2012.03.017

88. Kaufling J, Veinante P, Pawlowski SA, Freund-Mercier MJ, Barrot M. Afferents to the GABAergic tail of the ventral tegmental area in the rat. J Comp Neurol (2009) 513:597-621. doi:10.1002/cne.21983

89. Brinschwitz K, Dittgen A, Madai VI, Lommel R, Geisler S, Veh RW. Glutamatergic axons from the lateral habenula mainly terminate on GABAergic neurons of the ventral midbrain. Neuroscience (2010) 168:463-76. doi:10.1016/j.neuroscience.2010.03.050

90. Balcita-Pedicino JJ, Omelchenko N, Bell R, Sesack SR. The inhibitory influence of the lateral habenula on midbrain dopamine cells: ultrastructural evidence for indirect mediation via the rostromedial mesopontine tegmental nucleus. J Comp Neurol (2011) 519:1143-64. doi:10.1002/cne.22561

91. Hong S, Jhou TC, Smith M, Saleem KS, Hikosaka O. Negative reward signals from the lateral habenula to dopamine neurons are mediated by rostromedial tegmental nucleus in primates. J Neurosci (2011) 31:11457-71. doi:10.1523/ JNEUROSCI.1384-11.2011

92. Lammel S, Lim BK, Ran C, Huang KW, Betley MJ, Tye KM, et al. Inputspecific control of reward and aversion in the ventral tegmental area. Nature (2012) 491:212-7. doi:10.1038/nature11527

93. Kaufling J, Aston-Jones G. Persistent adaptations in afferents to ventral tegmental dopamine neurons after opiate withdrawal. J Neurosci (2015) 35:10290-303. doi:10.1523/JNEUROSCI.0715-15.2015

94. Lecca S, Melis M, Luchicchi A, Ennas MG, Castelli MP, Muntoni AL, et al. Effects of drugs of abuse on putative rostromedial tegmental neurons, inhibitory afferents to midbrain dopamine cells. Neuropsychopharmacology (2011) 36:589-602. doi:10.1038/npp.2010.190

95. Lecca S, Melis M, Luchicchi A, Muntoni AL, Pistis M. Inhibitory inputs from rostromedial tegmental neurons regulate spontaneous activity of midbrain dopamine cells and their responses to drugs of abuse. Neuropsychopharmacology (2012) 37:1164-76. doi:10.1038/npp.2011.302

96. Jalabert M, Bourdy R, Courtin J, Veinante P, Manzoni OJ, Barrot M, et al. Neuronal circuits underlying acute morphine action on dopamine neurons. Proc Natl Acad Sci U S A (2011) 108:16446-50. doi:10.1073/pnas.1105418108

97. Matsui A, Williams JT. Opioid-sensitive GABA inputs from rostromedial tegmental nucleus synapse onto midbrain dopamine neurons. J Neurosci (2011) 31:17729-35. doi:10.1523/JNEUROSCI.4570-11.2011

98. Siuda ER, Copits BA, Schmidt MJ, Baird MA, Al-Hasani R, Planer WJ, et al. Spatiotemporal control of opioid signaling and behavior. Neuron (2015) 86:923-35. doi:10.1016/j.neuron.2015.03.066

99. Perrotti LI, Bolanos CA, Choi KH, Russo SJ, Edwards S, Ulery PG, et al. DeltaFosB accumulates in a GABAergic cell population in the posterior tail of the ventral tegmental area after psychostimulant treatment. Eur J Neurosci (2005) 21:2817-24. doi:10.1111/j.1460-9568.2005.04110.x
100. Kaufling J, Veinante P, Pawlowski SA, Freund-Mercier MJ, Barrot M. gamma-Aminobutyric acid cells with cocaine-induced DeltaFosB in the ventral tegmental area innervate mesolimbic neurons. Biol Psychiatry (2010) 67:88-92. doi:10.1016/j.biopsych.2009.08.001

101. Mahler SV, Aston-Jones GS. Fos activation of selective afferents to ventral tegmental area during cue-induced reinstatement of cocaine seeking in rats. J Neurosci (2012) 32:13309-26. doi:10.1523/JNEUROSCI.2277-12.2012

102. Jhou TC, Good CH, Rowley CS, Xu SP, Wang H, Burnham NW, et al. Cocaine drives aversive conditioning via delayed activation of dopamine-responsive habenular and midbrain pathways. J Neurosci (2013) 33:7501-12. doi:10.1523/JNEUROSCI.3634-12.2013

103. Smith KS, Tindell AJ, Aldridge JW, Berridge KC. Ventral pallidum roles in reward and motivation. Behav Brain Res (2009) 196:155-67. doi:10.1016/j. bbr.2008.09.038

104. Root DH, Melendez RI, Zaborszky L, Napier TC. The ventral pallidum: subregion-specific functional anatomy and roles in motivated behaviors. Prog Neurobiol (2015) 130:29-70. doi:10.1016/j.pneurobio.2015.03.005

105. Hjelmstad GO, Xia Y, Margolis EB, Fields HL. Opioid modulation of ventral pallidal afferents to ventral tegmental area neurons. J Neurosci (2013) 33:6454-9. doi:10.1523/JNEUROSCI.0178-13.2013

106. Floresco SB, West AR, Ash B, Moore H, Grace AA. Afferent modulation of dopamine neuron firing differentially regulates tonic and phasic dopamine transmission. Nat Neurosci (2003) 6:968-73. doi:10.1038/nn1103

107. Johnson PI, Napier TC. Ventral pallidal injections of a mu antagonist block the development of behavioral sensitization to systemic morphine. Synapse (2000) 38:61-70. doi:10.1002/1098-2396(200010)38:1<61:AID-SYN7>3.0.CO;2-6

108. Mickiewicz AL, Dallimore JE, Napier TC. The ventral pallidum is critically involved in the development and expression of morphine-induced sensitization. Neuropsychopharmacology (2009) 34:874-86. doi:10.1038/npp.2008.111

109. Dallimore JE, Mickiewicz AL, Napier TC. Intra-ventral pallidal glutamate antagonists block expression of morphine-induced place preference. Behav Neurosci (2006) 120:1103-14. doi:10.1037/0735-7044.120.5.1103

110. Rademacher DJ, Kovacs B, Shen F, Napier TC, Meredith GE. The neural substrates of amphetamine conditioned place preference: implications for the formation of conditioned stimulus-reward associations. Eur J Neurosci (2006) 24:2089-97. doi:10.1111/j.1460-9568.2006.05066.x

111. Robledo P, Koob GF. Two discrete nucleus accumbens projection areas differentially mediate cocaine self-administration in the rat. Behav Brain Res (1993) 55:159-66. doi:10.1016/0166-4328(93)90112-4

112. Tang XC, McFarland K, Cagle S, Kalivas PW. Cocaine-induced reinstatement requires endogenous stimulation of mu-opioid receptors in the ventral pallidum. J Neurosci (2005) 25:4512-20. doi:10.1523/JNEUROSCI.0685-05.2005

113. Mahler SV, Vazey EM, Beckley JT, Keistler CR, McGlinchey EM, Kaufling J, et al. Designer receptors show role for ventral pallidum input to ventral tegmental area in cocaine seeking. Nat Neurosci (2014) 17:577-85. doi:10.1038/ nn.3664

114. Walker DL, Davis M. Double dissociation between the involvement of the bed nucleus of the stria terminalis and the central nucleus of the amygdala in startle increases produced by conditioned versus unconditioned fear. J Neurosci (1997) 17:9375-83.

115. Cecchi M, Khoshbouei H, Javors M, Morilak DA. Modulatory effects of norepinephrine in the lateral bed nucleus of the stria terminalis on behavioral and neuroendocrine responses to acute stress. Neuroscience (2002) 112:13-21. doi:10.1016/S0306-4522(02)00062-3

116. Fendt M, Endres T, Apfelbach R. Temporary inactivation of the bed nucleus of the stria terminalis but not of the amygdala blocks freezing induced by trimethylthiazoline, a component of fox feces. J Neurosci (2003) 23:23-8.

117. Sullivan GM, Apergis J, Bush DE, Johnson LR, Hou M, Ledoux JE. Lesions in the bed nucleus of the stria terminalis disrupt corticosterone and freezing responses elicited by a contextual but notby a specificcue-conditioned fear stimulus. Neuroscience (2004) 128:7-14. doi:10.1016/j.neuroscience.2004.06.015

118. Deyama S, Katayama T, Ohno A, Nakagawa T, Kaneko S, Yamaguchi $\mathrm{T}$, et al. Activation of the beta-adrenoceptor-protein kinase A signaling pathway within the ventral bed nucleus of the stria terminalis mediates the negative affective component of pain in rats. J Neurosci (2008) 28:7728-36. doi:10.1523/JNEUROSCI.1480-08.2008

119. Walker DL, Davis M. Role of the extended amygdala in short-duration versus sustained fear: a tribute to Dr. Lennart Heimer. Brain Struct Funct (2008) 213:29-42. doi:10.1007/s00429-008-0183-3 
120. Walker DL, Miles LA, Davis M. Selective participation of the bed nucleus of the stria terminalis and CRF in sustained anxiety-like versus phasic fear-like responses. Prog Neuropsychopharmacol Biol Psychiatry (2009) 33:1291-308. doi:10.1016/j.pnpbp.2009.06.022

121. Herman JP, Cullinan WE. Neurocircuitry of stress: central control of the hypothalamo-pituitary-adrenocortical axis. Trends Neurosci (1997) 20:78-84. doi:10.1016/S0166-2236(96)10069-2

122. Jalabert M, Aston-Jones G, Herzog E, Manzoni O, Georges F. Role of the bed nucleus of the stria terminalis in the control of ventral tegmental area dopamine neurons. Prog Neuropsychopharmacol Biol Psychiatry (2009) 33:1336-46. doi:10.1016/j.pnpbp.2009.07.010

123. Poulin JF, Arbour D, Laforest S, Drolet G. Neuroanatomical characterization of endogenous opioids in the bed nucleus of the stria terminalis. Prog Neuropsychopharmacol Biol Psychiatry (2009) 33:1356-65. doi:10.1016/j. pnpbp.2009.06.021

124. Kash TL, Pleil KE, Marcinkiewcz CA, Lowery-Gionta EG, Crowley N, Mazzone C, et al. Neuropeptide regulation of signaling and behavior in the BNST. Mol Cells (2015) 38:1-13. doi:10.14348/molcells.2015.2261

125. Georges F, Aston-Jones G. Potent regulation of midbrain dopamine neurons by the bed nucleus of the stria terminalis. J Neurosci (2001) 21:RC160.

126. Georges F, Aston-Jones G. Activation of ventral tegmental area cells by the bed nucleus of the stria terminalis: a novel excitatory amino acid input to midbrain dopamine neurons. J Neurosci (2002) 22:5173-87.

127. Wanat MJ, Bonci A, Phillips PE. CRF acts in the midbrain to attenuate accumbens dopamine release to rewards but not their predictors. Nat Neurosci (2013) 16:383-5. doi:10.1038/nn.3335

128. Kudo T, Uchigashima M, Miyazaki T, Konno K, Yamasaki M, Yanagawa Y, et al. Three types of neurochemical projection from the bed nucleus of the stria terminalis to the ventral tegmental area in adult mice. J Neurosci (2012) 32:18035-46. doi:10.1523/JNEUROSCI.4057-12.2012

129. Jennings JH, Sparta DR, Stamatakis AM, Ung RL, Pleil KE, Kash TL, et al. Distinct extended amygdala circuits for divergent motivational states. Nature (2013) 496:224-8. doi:10.1038/nature12041

130. Kudo T, Konno K, Uchigashima M, Yanagawa Y, Sora I, Minami M, et al. GABAergic neurons in the ventral tegmental area receive dual GABA/ enkephalin-mediated inhibitory inputs from the bed nucleus of the stria terminalis. Eur J Neurosci (2014) 39:1796-809. doi:10.1111/ejn.12503

131. Wang X, Cen X, Lu L. Noradrenaline in the bed nucleus of the stria terminalis is critical for stress-induced reactivation of morphine-conditioned place preference in rats. Eur J Pharmacol (2001) 432:153-61. doi:10.1016/ S0014-2999(01)01487-X

132. Briand LA, Vassoler FM, Pierce RC, Valentino RJ, Blendy JA. Ventral tegmental afferents in stress-induced reinstatement: the role of cAMP response element-binding protein. JNeurosci (2010) 30:16149-59. doi:10.1523/ JNEUROSCI.2827-10.2010

133. Glangetas C, Fois GR, Jalabert M, Lecca S, Valentinova K, Meye FJ, et al. Ventral subiculum stimulation promotes persistent hyperactivity of dopamine neurons and facilitates behavioral effects of cocaine. Cell Rep (2015) 13(10):2287-96. doi:10.1016/j.celrep.2015.10.076

134. Sartor GC, Aston-Jones G. Regulation of the ventral tegmental area by the bed nucleus of the stria terminalis is required for expression of cocaine preference. Eur J Neurosci (2012) 36:3549-58. doi:10.1111/j.1460-9568.2012.08277.x

135. Marchant NJ, Millan EZ, McNally GP. The hypothalamus and the neurobiology of drug seeking. Cell Mol Life Sci (2012) 69:581-97. doi:10.1007/ s00018-011-0817-0

136. Kallo I, Molnar CS, Szoke S, Fekete C, Hrabovszky E, Liposits Z. Area-specific analysis of the distribution of hypothalamic neurons projecting to the rat ventral tegmental area, with special reference to the GABAergic and glutamatergic efferents. Front Neuroanat (2015) 9:112. doi:10.3389/fnana.2015.00112

137. Geisler S, Zahm DS. Neurotensin afferents of the ventral tegmental area in the rat: [1] re-examination of their origins and [2] responses to acute psychostimulant and antipsychotic drug administration. Eur J Neurosci (2006) 24:116-34. doi:10.1111/j.1460-9568.2006.04928.x

138. Cason AM, Smith RJ, Tahsili-Fahadan P, Moorman DE, Sartor GC, AstonJones G. Role of orexin/hypocretin in reward-seeking and addiction: implications for obesity. Physiol Behav (2010) 100:419-28. doi:10.1016/j. physbeh.2010.03.009

139. Maeda H, Mogenson GJ. A comparison of the effects of electrical stimulation of the lateral and ventromedial hypothalamus on the activity of neurons in the ventral tegmental area and substantia nigra. Brain Res Bull (1981) 7:283-91. doi:10.1016/0361-9230(81)90020-4

140. Nakajima S, O'Regan NB. The effects of dopaminergic agonists and antagonists on the frequency-response function for hypothalamic self-stimulation in the rat. Pharmacol Biochem Behav (1991) 39:465-8. doi:10.1016/0091-3057(91)90209-K

141. You ZB, Chen YQ, Wise RA. Dopamine and glutamate release in the nucleus accumbens and ventral tegmental area of rat following lateral hypothalamic self-stimulation. Neuroscience (2001) 107:629-39. doi:10.1016/ S0306-4522(01)00379-7

142. Kempadoo KA, Tourino C, Cho SL, Magnani F, Leinninger GM, Stuber GD, et al. Hypothalamic neurotensin projections promote reward by enhancing glutamate transmission in the VTA. JNeurosci (2013) 33:7618-26. doi:10.1523/JNEUROSCI.2588-12.2013

143. Mahler SV, Moorman DE, Smith RJ, James MH, Aston-Jones G. Motivational activation: a unifying hypothesis of orexin/hypocretin function. Nat Neurosci (2014) 17:1298-303. doi:10.1038/nn.3810

144. Peyron C, Tighe DK, van den Pol AN, de Lecea L, Heller HC, Sutcliffe JG, et al. Neurons containing hypocretin (orexin) project to multiple neuronal systems. J Neurosci (1998) 18:9996-10015.

145. Narita M, Nagumo Y, Hashimoto S, Narita M, Khotib J, Miyatake M, et al. Direct involvement of orexinergic systems in the activation of the mesolimbic dopamine pathway and related behaviors induced by morphine. J Neurosci (2006) 26:398-405. doi:10.1523/JNEUROSCI.2761-05.2006

146. Harris GC, Wimmer M, Randall-Thompson JF, Aston-Jones G. Lateral hypothalamic orexin neurons are critically involved in learning to associate an environment with morphine reward. Behav Brain Res (2007) 183:43-51. doi:10.1016/j.bbr.2007.05.025

147. Georgescu D, Zachariou V, Barrot M, Mieda M, Willie JT, Eisch AJ, et al. Involvement of the lateral hypothalamic peptide orexin in morphine dependence and withdrawal. J Neurosci (2003) 23:3106-11.

148. Borgland SL, Taha SA, Sarti F, Fields HL, Bonci A. Orexin A in the VTA is critical for the induction of synaptic plasticity and behavioral sensitization to cocaine. Neuron (2006) 49:589-601. doi:10.1016/j.neuron.2006.01.016

149. Muschamp JW, Hollander JA, Thompson JL, Voren G, Hassinger LC, Onvani S, et al. Hypocretin (orexin) facilitates reward by attenuating the antireward effects of its cotransmitter dynorphin in ventral tegmental area. Proc Natl Acad Sci U S A (2014) 111:E1648-55. doi:10.1073/ pnas. 1315542111

150. James MH, Charnley JL, Levi EM, Jones E, Yeoh JW, Smith DW, et al. Orexin-1 receptor signalling within the ventral tegmental area, but not the paraventricular thalamus, is critical to regulating cue-induced reinstatement of cocaine-seeking. Int J Neuropsychopharmacol (2011) 14:684-90. doi:10.1017/S1461145711000423

151. Inglis WL, Olmstead MC, Robbins TW. Pedunculopontine tegmental nucleus lesions impair stimulus - reward learning in autoshaping and conditioned reinforcement paradigms. Behav Neurosci (2000) 114:285-94. doi:10.1037/0735-7044.114.2.285

152. Inglis WL, Olmstead MC, Robbins TW. Selective deficits in attentional performance on the 5-choice serial reaction time task following pedunculopontine tegmental nucleus lesions. Behav Brain Res (2001) 123:117-31. doi:10.1016/S0166-4328(01)00181-4

153. Yeomans JS. Muscarinic receptors in brain stem and mesopontine cholinergic arousal functions. Handb Exp Pharmacol (2012):243-59. doi:10.1007/978-3-642-23274-9_11

154. Steidl S, Veverka K. Optogenetic excitation of LDTg axons in the VTA reinforces operant responding in rats. Brain Res (2015) 1614:86-93. doi:10.1016/j. brainres.2015.04.021

155. Oakman SA, Faris PL, Kerr PE, Cozzari C, Hartman BK. Distribution of pontomesencephalic cholinergic neurons projecting to substantia nigra differs significantly from those projecting to ventral tegmental area. J Neurosci (1995) 15:5859-69.

156. Wang HL, Morales M. Pedunculopontine and laterodorsal tegmental nuclei contain distinct populations of cholinergic, glutamatergic and GABAergic neurons in the rat. Eur J Neurosci (2009) 29:340-58. doi:10.1111/j.1460-9568.2008.06576.x

157. Omelchenko N, Sesack SR. Laterodorsal tegmental projections to identified cell populations in the rat ventral tegmental area. J Comp Neurol (2005) 483:217-35. doi:10.1002/cne.20417 
158. Lodge DJ, Grace AA. The laterodorsal tegmentum is essential for burst firing of ventral tegmental area dopamine neurons. Proc Natl Acad Sci U S A (2006) 103:5167-72. doi:10.1073/pnas.0510715103

159. Shinohara F, Kihara Y, Ide S, Minami M, Kaneda K. Critical role of cholinergic transmission from the laterodorsal tegmental nucleus to the ventral tegmental area in cocaine-induced place preference. Neuropharmacology (2014) 79:573-9. doi:10.1016/j.neuropharm.2014.01.019

160. Schmidt HD, Famous KR, Pierce RC. The limbic circuitry underlying cocaine seeking encompasses the PPTg/LDT. Eur J Neurosci (2009) 30:1358-69. doi:10.1111/j.1460-9568.2009.06904.x

161. Steidl S, Cardiff KM, Wise RA. Increased latencies to initiate cocaine self-administration following laterodorsal tegmental nucleus lesions. Behav Brain Res (2015) 287:82-8. doi:10.1016/j.bbr.2015.02.049

162. Pan WX, Hyland BI. Pedunculopontine tegmental nucleus controls conditioned responses of midbrain dopamine neurons in behaving rats. J Neurosci (2005) 25:4725-32. doi:10.1523/JNEUROSCI.0277-05.2005

163. Good CH, Lupica CR. Properties of distinct ventral tegmental area synapses activated via pedunculopontine or ventral tegmental area stimulation in vitro. J Physiol (2009) 587:1233-47. doi:10.1113/jphysiol.2008.164194

164. Bechara A,van der Kooy D. Lesions of the tegmental pedunculopontinenucleus: effects on the locomotor activity induced by morphine and amphetamine. Pharmacol Biochem Behav (1992) 42:9-18. doi:10.1016/0091-3057(92)90438-L

165. Olmstead MC, Franklin KB. Effects of pedunculopontine tegmental nucleus lesions on morphine-induced conditioned place preference and analgesia in the formalintest.Neuroscience(1993)57:411-8.doi:10.1016/0306-4522(93)90072-N

166. Olmstead MC, Munn EM, Franklin KB, Wise RA. Effects of pedunculopontine tegmental nucleus lesions on responding for intravenous heroin under different schedules of reinforcement. J Neurosci (1998) 18:5035-44.

167. Steidl S, Wang H, Wise RA. Lesions of cholinergic pedunculopontine tegmental nucleus neurons fail to affect cocaine or heroin self-administration or conditioned place preference in rats. PLoS One (2014) 9:e84412. doi:10.1371/ journal.pone.0084412

168. Charara A, Parent A. Chemoarchitecture of the primate dorsal raphe nucleus. J Chem Neuroanat (1998) 15:111-27. doi:10.1016/S0891-0618(98)00036-2

169. Dougalis AG, Matthews GA, Bishop MW, Brischoux F, Kobayashi K, Ungless MA. Functional properties of dopamine neurons and co-expression of vasoactive intestinal polypeptide in the dorsal raphe nucleus and ventro-lateral periaqueductal grey. Eur J Neurosci (2012) 36:3322-32. doi:10.1111/j.1460-9568.2012.08255.x

170. Lowry CA, Hale MW, Evans AK, Heerkens J, Staub DR, Gasser PJ, et al. Serotonergic systems, anxiety, and affective disorder: focus on the dorsomedial part of the dorsal raphe nucleus. Ann N Y Acad Sci (2008) 1148:86-94. doi:10.1196/annals.1410.004

171. Liu Z, Zhou J, Li Y, Hu F, Lu Y, Ma M, et al. Dorsal raphe neurons signal reward through 5-HT and glutamate. Neuron (2014) 81:1360-74. doi:10.1016/j. neuron.2014.02.010

172. Pessia M, Jiang ZG, North RA, Johnson SW. Actions of 5-hydroxytryptamine on ventral tegmental area neurons of the rat in vitro. Brain Res (1994) 654:324-30. doi:10.1016/0006-8993(94)90495-2

173. Guan XM, McBride WJ. Serotonin microinfusion into the ventral tegmental area increases accumbens dopamine release. Brain Res Bull (1989) 23:541-7. doi:10.1016/0361-9230(89)90198-6

174. Muller CP, Homberg JR. The role of serotonin in drug use and addiction. Behav Brain Res (2015) 277:146-92. doi:10.1016/j.bbr.2014.04.007

175. Qi J, Zhang S, Wang HL, Wang H, de Jesus Aceves Buendia J, Hoffman AF, et al. A glutamatergic reward input from the dorsal raphe to ventral tegmental area dopamine neurons. Nat Commun (2014) 5:5390. doi:10.1038/ncomms6390

176. McDevitt RA, Tiran-Cappello A, Shen H, Balderas I, Britt JP, Marino RA, et al. Serotonergic versus nonserotonergic dorsal raphe projection neurons: differential participation in reward circuitry. Cell Rep (2014) 8:1857-69. doi:10.1016/j.celrep.2014.08.037

177. Rahman S, McBride WJ. Feedback control of mesolimbic somatodendritic dopamine release in rat brain. JNeurochem (2000) 74:684-92. doi:10.1046/j.1471-4159.2000.740684.x

178. Xia Y, Driscoll JR, Wilbrecht L, Margolis EB, Fields HL, Hjelmstad GO. Nucleus accumbens medium spiny neurons target non-dopaminergic neurons in the ventral tegmental area. J Neurosci (2011) 31:7811-6. doi:10.1523/ JNEUROSCI.1504-11.2011
179. Bocklisch C, Pascoli V, Wong JC, House DR, Yvon C, de Roo M, et al. Cocaine disinhibits dopamine neurons by potentiation of GABA transmission in the ventral tegmental area. Science (2013) 341:1521-5. doi:10.1126/ science. 1237059

180. Floresco SB. Prefrontal dopamine and behavioral flexibility: shifting from an "inverted-U" toward a family of functions. Front Neurosci (2013) 7:62. doi:10.3389/fnins.2013.00062

181. Colussi-Mas J, Geisler S, Zimmer L, Zahm DS, Berod A. Activation of afferents to the ventral tegmental area in response to acute amphetamine: a double-labelling study. Eur J Neurosci (2007) 26:1011-25. doi:10.1111/j.1460-9568.2007.05738.x

182. Sesack SR, Carr DB, Omelchenko N, Pinto A. Anatomical substrates for glutamate-dopamine interactions: evidence for specificity of connections and extrasynaptic actions. Ann N Y Acad Sci (2003) 1003:36-52. doi:10.1196/ annals. 1300.066

183. Gariano RF, Groves PM. Burst firing induced in midbrain dopamine neurons by stimulation of the medial prefrontal and anterior cingulate cortices. Brain Res (1988) 462:194-8. doi:10.1016/0006-8993(88)90606-3

184. Lodge DJ. The medial prefrontal and orbitofrontal cortices differentially regulate dopamine system function. Neuropsychopharmacology (2011) 36:1227-36. doi:10.1038/npp.2011.7

185. Stopper CM, Tse MT, Montes DR, Wiedman CR, Floresco SB. Overriding phasic dopamine signals redirects action selection during risk/reward decision making. Neuron (2014) 84:177-89. doi:10.1016/j.neuron.2014.08.033

186. Frankle WG, Laruelle M, Haber SN. Prefrontal cortical projections to the midbrain in primates: evidence for a sparse connection. Neuropsychopharmacology (2006) 31:1627-36. doi:10.1038/sj.npp.1300990

187. Balleine BW, Killcross S. Parallel incentive processing: an integrated view of amygdala function. Trends Neurosci (2006) 29:272-9. doi:10.1016/j. tins.2006.03.002

188. Janak PH, Tye KM. From circuits to behaviour in the amygdala. Nature (2015) 517:284-92. doi:10.1038/nature14188

189. Fudge JL, Haber SN. The central nucleus of the amygdala projection to dopamine subpopulations in primates. Neuroscience (2000) 97:479-94. doi:10.1016/S0306-4522(00)00092-0

190. Ehrlich I, Humeau Y, Grenier F, Ciocchi S, Herry C, Luthi A. Amygdala inhibitory circuits and the control of fear memory. Neuron (2009) 62:757-71. doi:10.1016/j.neuron.2009.05.026

191. Holland PC, Gallagher M. Double dissociation of the effects of lesions of basolateral and central amygdala on conditioned stimulus-potentiated feeding and Pavlovian-instrumental transfer. Eur J Neurosci (2003) 17:1680-94. doi:10.1046/j.1460-9568.2003.02585.x

192. Corbit LH, Balleine BW. Double dissociation of basolateral and central amygdala lesions on the general and outcome-specific forms of pavlovian-instrumental transfer. J Neurosci (2005) 25:962-70. doi:10.1523/ JNEUROSCI.4507-04.2005

193. Kruzich PJ, See RE. Differential contributions of the basolateral and central amygdala in the acquisition and expression of conditioned relapse to cocaine-seeking behavior. J Neurosci (2001) 21:RC155.

194. Shaham Y, Erb S, Stewart J. Stress-induced relapse to heroin and cocaine seeking in rats: a review. Brain Res Brain Res Rev (2000) 33:13-33. doi:10.1016/ S0165-0173(00)00024-2

195. Leri F, Flores J, Rodaros D, Stewart J. Blockade of stress-induced but not cocaine-induced reinstatement by infusion of noradrenergic antagonists into the bed nucleus of the stria terminalis or the central nucleus of the amygdala. J Neurosci (2002) 22:5713-8.

196. Volkow ND, Baler RD. Addiction science: uncovering neurobiological complexity. Neuropharmacology (2014) 76(Pt B):235-49. doi:10.1016/j. neuropharm.2013.05.007

197. Kauer JA. Learning mechanisms in addiction: synaptic plasticity in the ventral tegmental area as a result of exposure to drugs of abuse. Annu Rev Physiol (2004) 66:447-75. doi:10.1146/annurev.physiol.66.032102.112534

198. Luscher C, Malenka RC. Drug-evoked synaptic plasticity in addiction: from molecular changes to circuit remodeling. Neuron (2011) 69:650-63. doi:10.1016/j.neuron.2011.01.017

199. Sun W. Dopamine neurons in the ventral tegmental area: drug-induced synaptic plasticity and its role in relapse to drug-seeking behavior. Curr Drug Abuse Rev (2011) 4:270-85. doi:10.2174/1874473711104040270 
200. Luscher C. Cocaine-evoked synaptic plasticity of excitatory transmission in the ventral tegmental area. Cold Spring Harb Perspect Med (2013) 3:a012013. doi:10.1101/cshperspect.a012013

201. van Huijstee AN, Mansvelder HD. Glutamatergic synaptic plasticity in the mesocorticolimbic system in addiction. Front Cell Neurosci (2014) 8:466. doi:10.3389/fncel.2014.00466

202. Ungless MA, Whistler JL, Malenka RC, Bonci A. Single cocaine exposure in vivo induces long-term potentiation in dopamine neurons. Nature (2001) 411:583-7. doi:10.1038/35079077

203. Saal D, Dong Y, Bonci A, Malenka RC. Drugs of abuse and stress trigger a common synaptic adaptation in dopamine neurons. Neuron (2003) 37:577-82. doi:10.1016/S0896-6273(03)00021-7

204. Borgland SL, Malenka RC, Bonci A. Acute and chronic cocaine-induced potentiation of synaptic strength in the ventral tegmental area: electrophysiological and behavioral correlates in individual rats. J Neurosci (2004) 24:7482-90. doi:10.1523/JNEUROSCI.1312-04.2004

205. Bellone C, Luscher C. Cocaine triggered AMPA receptor redistribution is reversed in vivo by mGluR-dependent long-term depression. Nat Neurosci (2006) 9:636-41. doi:10.1038/nn1682

206. Chen BT, Bowers MS, Martin M, Hopf FW, Guillory AM, Carelli RM, et al. Cocaine but not natural reward self-administration nor passive cocaine infusion produces persistent LTP in the VTA. Neuron (2008) 59:288-97. doi:10.1016/j.neuron.2008.05.024

207. Wanat MJ, Bonci A. Dose-dependent changes in the synaptic strength on dopamine neurons and locomotor activity after cocaine exposure. Synapse (2008) 62:790-5. doi:10.1002/syn.20546

208. Mameli M, Bellone C, Brown MT, Luscher C. Cocaine inverts rules for synaptic plasticity of glutamate transmission in the ventral tegmental area. Nat Neurosci (2011) 14:414-6. doi:10.1038/nn.2763

209. Liu QS, Pu L, Poo MM. Repeated cocaine exposure in vivo facilitates LTP induction in midbrain dopamine neurons. Nature (2005) 437:1027-31. doi:10.1038/nature04050

210. Nugent FS, Penick EC, Kauer JA. Opioids block long-term potentiation of inhibitory synapses. Nature (2007) 446:1086-90. doi:10.1038/nature05726

211. Nugent FS, Niehaus JL, Kauer JA. PKG and PKA signaling in LTP at GABAergic synapses. Neuropsychopharmacology (2009) 34:1829-42. doi:10.1038/npp.2009.5

212. Good CH, Lupica CR. Afferent-specific AMPA receptor subunit composition and regulation of synaptic plasticity in midbrain dopamine neurons by abused drugs. J Neurosci (2010) 30:7900-9. doi:10.1523/ JNEUROSCI.1507-10.2010

213. Stotts AL, Dodrill CL, Kosten TR. Opioid dependence treatment: options in pharmacotherapy. Expert Opin Pharmacother (2009) 10:1727-40. doi:10.1517/14656560903037168

214. Amen SL, Piacentine LB, Ahmad ME, Li SJ, Mantsch JR, Risinger RC, et al. Repeated $\mathrm{N}$-acetyl cysteine reduces cocaine seeking in rodents and craving in cocaine-dependent humans. Neuropsychopharmacology (2011) 36:871-8. doi:10.1038/npp.2010.226

215. McClure EA, Gipson CD, Malcolm RJ, Kalivas PW, Gray KM. Potential role of $\mathrm{N}$-acetylcysteine in the management of substance use disorders. CNS Drugs (2014) 28:95-106. doi:10.1007/s40263-014-0142-x

216. McClure EA, Baker NL, Gipson CD, Carpenter MJ, Roper AP, Froeliger BE, et al. An open-label pilot trial of $\mathrm{N}$-acetylcysteine and varenicline in adult cigarette smokers. Am J Drug Alcohol Abuse (2015) 41:52-6. doi:10.3109/0 0952990.2014.933839

217. Reissner KJ, Gipson CD, Tran PK, Knackstedt LA, Scofield MD, Kalivas PW. Glutamate transporter GLT-1 mediates N-acetylcysteine inhibition of cocaine reinstatement. Addict Biol (2015) 20:316-23. doi:10.1111/adb.12127

218. Roerecke M, Sorensen P, Laramee P, Rahhali N, Rehm J. Clinical relevance of nalmefene versus placebo in alcohol treatment: reduction in mortality risk. J Psychopharmacol (2015) 29:1152-8. doi:10.1177/0269881115602487

219. Martinotti G, Di Nicola M, Janiri L. Efficacy and safety of aripiprazole in alcohol dependence. Am JDrug Alcohol Abuse (2007) 33:393-401. doi:10.1080/00952990701313660

220. Martinotti G. Pregabalin in clinical psychiatry and addiction: pros and cons. Expert Opin Investig Drugs (2012) 21:1243-5. doi:10.1517/13543784.2012. 703179

221. Addolorato G, Leggio L, Ferrulli A, Cardone S, Bedogni G, Caputo F, et al. Dose-response effect of baclofen in reducing daily alcohol intake in alcohol dependence: secondary analysis of a randomized, double-blind, placebo-controlled trial. Alcohol Alcohol (2011) 46:312-7. doi:10.1093/ alcalc/agr017

222. Simpson TL, Malte CA, Dietel B, Tell D, Pocock I, Lyons R, et al. A pilot trial of prazosin, an alpha-1 adrenergic antagonist, for comorbid alcohol dependence and posttraumatic stress disorder. Alcohol Clin Exp Res (2015) 39:808-17. doi:10.1111/acer.12703

223. Gessa GL, Serra S, Vacca G, Carai MA, Colombo G. Suppressing effect of the cannabinoid CB1 receptor antagonist, SR147778, on alcohol intake and motivational properties of alcohol in alcohol-preferring $\mathrm{sP}$ rats. Alcohol Alcohol (2005) 40:46-53. doi:10.1093/alcalc/agh114

224. Cheer JF, Wassum KM, Sombers LA, Heien ML, Ariansen JL, Aragona $B J$, et al. Phasic dopamine release evoked by abused substances requires cannabinoid receptor activation. J Neurosci (2007) 27:791-5. doi:10.1523/ JNEUROSCI.4152-06.2007

225. Topol EJ, Bousser MG, Fox KA, Creager MA, Despres JP, Easton JD, et al. Rimonabant for prevention of cardiovascular events (CRESCENDO): a randomised, multicentre, placebo-controlled trial. Lancet (2010) 376:517-23. doi:10.1016/S0140-6736(10)60935-X

226. Creed M, Pascoli VJ, Luscher C. Addiction therapy. Refining deep brain stimulation to emulate optogenetic treatment of synaptic pathology. Science (2015) 347:659-64. doi:10.1126/science.1260776

227. Liu HY, Jin J, Tang JS, Sun WX, Jia H, Yang XP, et al. Chronic deep brain stimulation in the rat nucleus accumbens and its effect on morphine reinforcement. Addict Biol (2008) 13:40-6. doi:10.1111/j.1369-1600.2007.00088.x

228. Guo L, Zhou H, Wang R, Xu J, Zhou W, Zhang F, et al. DBS of nucleus accumbens on heroin seeking behaviors in self-administering rats. Drug Alcohol Depend (2013) 129:70-81. doi:10.1016/j.drugalcdep.2012.09.012

229. Vassoler FM, Schmidt HD, Gerard ME, Famous KR, Ciraulo DA, Kornetsky C, et al. Deep brain stimulation of the nucleus accumbens shell attenuates cocaine priming-induced reinstatement of drug seeking in rats. J Neurosci (2008) 28:8735-9. doi:10.1523/JNEUROSCI.5277-07.2008

230. Guercio LA, Schmidt HD, Pierce RC. Deep brain stimulation of the nucleus accumbens shell attenuates cue-induced reinstatement of both cocaine and sucrose seeking in rats. Behav Brain Res (2015) 281:125-30. doi:10.1016/j. bbr.2014.12.025

231. Hamilton J, Lee J, Canales JJ. Chronic unilateral stimulation of the nucleus accumbens at high or low frequencies attenuates relapse to cocaine seeking in an animal model. Brain Stimul (2015) 8:57-63. doi:10.1016/j.brs.2014.09.018

232. Friedman A, Lax E, Dikshtein Y, Abraham L, Flaumenhaft Y, Sudai E, et al. Electrical stimulation of the lateral habenula produces enduring inhibitory effect on cocaine seeking behavior. Neuropharmacology (2010) 59:452-9. doi:10.1016/j.neuropharm.2010.06.008

233. Zhou H, Xu J, Jiang J. Deep brain stimulation of nucleus accumbens on heroin-seeking behaviors: a case report. Biol Psychiatry (2011) 69:e41-2. doi:10.1016/j.biopsych.2011.02.012

234. Valencia-Alfonso CE, Luigjes J, Smolders R, Cohen MX, Levar N, Mazaheri A, et al. Effective deep brain stimulation in heroin addiction: a case report with complementary intracranial electroencephalogram. Biol Psychiatry (2012) 71:e35-7. doi:10.1016/j.biopsych.2011.12.013

235. Terraneo A, Leggio L, Saladini M, Ermani M, Bonci A, Gallimberti L. Transcranial magnetic stimulation of dorsolateral prefrontal cortex reduces cocaine use: a pilot study. Eur Neuropsychopharmacol (2016) 26(1):37-44. doi:10.1016/j.euroneuro.2015.11.011

236. Enokibara M, Trevizol A, Shiozawa P, Cordeiro Q. Establishing an effective TMS protocol for craving in substance addiction: is it possible? Am J Addict (2016) 25:28-30. doi:10.1111/ajad.12309

237. Britt JP, Bonci A. Optogenetic interrogations of the neural circuits underlying addiction. Curr Opin Neurobiol (2013) 23:539-45. doi:10.1016/j. conb.2013.01.010

Conflict of Interest Statement: The authors declare that the research was conducted in the absence of any commercial or financial relationships that could be construed as a potential conflict of interest.

Copyright $\odot 2016$ Oliva and Wanat. This is an open-access article distributed under the terms of the Creative Commons Attribution License (CC BY). The use, distribution or reproduction in other forums is permitted, provided the original author(s) or licensor are credited and that the original publication in this journal is cited, in accordance with accepted academic practice. No use, distribution or reproduction is permitted which does not comply with these terms. 